\title{
Social benefit cost analysis of ecosystem-based climate change adaptations: a community-level case study in Tanna Island, Vanuatu
}

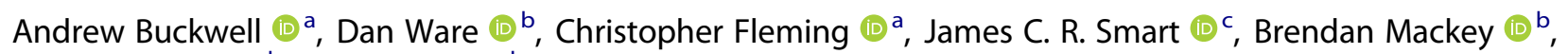 \\ Johanna Nalau $\mathbb{1}^{\mathrm{b}}$ and Allan Dan ${ }^{\mathrm{d}}$
}

${ }^{a}$ Griffith Business School, Griffith University, South Bank, Australia; ${ }^{b}$ Griffith Climate Change Response Program, Griffith University, Southport, Australia; ${ }^{c}$ Australian Rivers Institute and School of Environment, Griffith University, Nathan, Australia; ${ }^{d}$ Secretariat of the Pacific Regional Environment Programme, Apia, Samoa

\begin{abstract}
Small island developing states are vulnerable to the impacts of climate change, including more intense and frequent extreme weather, warming temperatures, coastal erosion, inundation, and coral bleaching. Locally-specific natural resource threats, associated with population growth and tourism, exacerbate these systemic risks, which are particularly acute where community well-being is subsistence-based and directly reliant on ecosystem services. Garden productivity is falling as the cropping/fallow cycle intensifies and culturally and there is loss of observance of traditional resource taboos, eroding the effectiveness of customary management. Ecosystem based adaptations (EbA) provide a fruitful range of interventions and are beginning to attract development funding. We undertook a social benefit cost analysis for a suite of interconnecting EbAs for Tanna in Vanuatu. We found that funds targeted at increasing the productivity of the gardens returns significant social benefit. This also reduces pressure on natural resource threats and can potentially be adopted by all households on Tanna. In addition, increasing the community's capacity to balance formal forest and reef conservation with customary management can provide small, but nevertheless important complimentary benefits. Our programme design included interlinking activities, including a series of demonstration garden plots, extension officers, community radio, a community ranger programme and a tree nursery.
\end{abstract}

ARTICLE HISTORY

Received 10 February 2019

Accepted 4 July 2019

\section{KEYWORDS}

Ecosystem-based adaptation climate change adaptation; Vanuatu; food security; farming extension

\section{Introduction}

Small Island Developing States (SIDS) commonly rate as highly vulnerable to the biophysical impacts of climate change, including more intense or frequent extreme weather events, warming temperatures, coastal erosion, inundation, and coral bleaching. Most SIDS rural communities are subsistence-based and therefore human well-being is directly related to ecosystem service (ES) delivery, which is affected by these impacts, risking food insecurity and malnutrition (Carpenter et al., 2006; Millennium Ecosystem Assessment, 2005; Savage, McIver, \& Schubert, 2019). In addition, for particular SIDS, non-climate changerelated risks, such as seismic and volcanic activity, further increase sudden-onset perturbations in ES delivery. Social and economic development and demographic pressures also play their part.

To mitigate these climate risks and to work towards the goals of the United Nations 2030 Agenda for Sustainable Development (the Sustainable Development Goals, or 'SDGs') (UN, 2018), funding agencies, such as the Global Environment Fund and the Green Climate Fund, and global development banks will need to commit an estimated US\$ 140-300 billion (bn) per year by 2030 , rising to US $\$ 280-500$ bn per year by 2050 , to climate change adaptation projects (UNEP, 2016). Steering this money towards adaptation projects with high social rates of return is key to meeting the climate challenges and achieving the SDGs. However, assessing or projecting social rates of return for adaptation projects remains a challenge, given a lack of systematic outcomes that define project 'success', the paucity of ES valuation data for calculating social benefits, the long delay between implementation and delivery of outcomes, and heterogeneity in locally-specific risks, cultures and institutions (Adger, Arnell, \& Tompkins, 2005; BerrangFord, Ford, \& Paterson, 2011; Ford, Berrang-Ford, Lesnikowski, Barrera, \& Heymann, 2013; Hasan, Smart, Fleming, \& Mackey, 2018).

Climate change adaptation (CCA) can be defined broadly as adjustments to social-ecological systems in response to actual or expected climatic changes that ease any adverse effects or take advantage of new opportunities (Adger et al., 2005; Betzold, 2015; IPCC, 2014). By adapting management of natural resources and socio-economic systems to climate changes, communities can reduce risks and lessen potential future damages that might otherwise occur (Leary, 1999). Ecosystem-based adaptation (EbA) to climate change describes a potentially fruitful class of CCA interventions. $\mathrm{EbA}$ is the deployment of biodiversity and ESs to help communities adapt to the adverse effects of climate change - it is not simply habitat conservation for its own sake (Andrade et al., 2011; 
FEBA, 2018; Munang et al., 2013; Nalau, Becken, \& Mackey, 2018; World Bank, 2009). EbA links habitat conservation and active, adaptive management with broader social and economic development strategies that assist communities adapt to trends and shocks associated with climate change and, in parallel, to improve social and economic well-being. EbA interventions are not rigidly-defined, but can be best understood in terms of their position on a continuum from 'hard', infrastructurebased interventions to those that solely deploy ecosystems in adaptation (FEBA, 2018, pp. 8-10). In this sense, EbAs work with nature and natural processes (even when containing some hard components) and therefore provide the support and space to assist habitats to also adapt to changing conditions in ways that are beneficial to human society.

Particularly for SIDS, EbA presents advantages over hard adaptation approaches (Mackey \& Ware, 2018). Whilst hard climate change adaptations, such as seawalls, manage risks of very specific hazards (inundation from sea water during storm surges, for example), and potentially manage them extremely well, EbAs tend to manage such risks with less certainty, but provide numerous co-benefits. As such, EbA promotes social equity and is pro-poor, as these co-benefits tend to flow indiscriminately to the wider community as public goods, rather than as specific, private benefit, which also potentially generates a negative externality if the investment has deleterious impacts on nearby habitats and communities. For example, the regeneration of a mangrove forest to provide wave energy protection to coastal communities during storm events also provides habitat to deliver a wider range of ESs, such as nurseries for marine fauna that support more sustainable fishing (Riley et al., 2009). Particularly for SIDS, such co-benefits are the mainstay of agriculture, fisheries and community well-being (Mackey et al., 2017; UNDP, 2010). EbA can also contribute towards national development plans, generally align with SDGs, and may provide carbon mitigation opportunities (Republic of Vanuatu, 2016b). Potentially, EbAs are the cheapest, safest and easiest solutions and sometimes the only feasible and practical solution as they are amenable to bottom-up community-based adaptation approaches (Betzold, 2015). They also deploy appropriate technology and can be utilized in locations where specialist engineering capacity can be scarce.

The foci of funded EbA projects in Pacific SIDS is dominated by 'downstream' activities, such as ecosystem asset conservation or augmentation in the service of adaptation and by capacity building and community planning activities to improve adaptive capacity. Projects that tackle 'upstream' factors - factors that reduce anthropogenic stressors to existing habitats, such as the impact of unsustainable agricultural practices - have tended to be less successful in securing funding. Approximately 5\% of EbA projects identified in a dataset compiled by Hasan et al. (2018) list directly improving agricultural productivity, or reducing the impact of agricultural activities on natural habitats, as primary activities (though 'food security' is a commonly cited outcome). Notwithstanding, there is policy support at the national level for such projects. The Vanuatu National Sustainable Development Plan (NSDP) 2016-2030 (Republic of Vanuatu, 2016b) connects EbA, food production, and ES integrity. The environment pillar links conservation of the natural environment to ecosystem service provision of 'food, cultural, economic and ecological needs' (2016b, p. 13). Specifically, objective ENV 1.5 seeks to do this by ' $[\mathrm{e}]$ nhancing traditional agricultural practices, focusing on disaster risk reduction and climate change adaptation' (2016b, p. 13).

In this case study we assess and compare projects that focus on activities that increase community resilience through directly investing in ecosystem conservation and on reducing anthropogenic stressors to remaining habitats and ecosystem functions. Our case study presents a social benefit cost analysis (SBCA) for a series of interconnecting EbA projects proposed for possible implementation on Tanna island (hereafter, Tanna) in the Republic of Vanuatu. These project proposals arose from the Pacific Ecosystem-based Adaptation to Climate Change Project (PEBACC) a project, which explored the potential for EbA to be integrated into 'development, climate change adaptation and natural resource management policy and planning processes in [...] Pacific island countries' (SPREP, 2018). The first stage of this project involved, among other things, an assessment of ES benefit flows and climate change-related risks to the resilience of the (predominantly) rural communities on Tanna (Mackey et al., 2017). Here we focus on a programme of possible EbA interventions to address these risks, based on two interlinked projects: (i) implementation of demonstration garden plots and deployment of agricultural extension officers, which tackles upstream stressors to habitats; and (ii) from a downstream perspective, technical and logistical support for the establishment of a series of community-based conservation areas (marine and terrestrial) and accompanying community ranger programme to rebuild habitats already under threat from climate change.

To inform and develop these proposals, between November 2016 and March 2017, we undertook several stakeholder consultations on Tanna to ensure the research team had a grounded understanding of the everyday vulnerabilities that underlie the social and environmental context. The consultations included workshops, community focus group discussions in selected communities, guided forest and reef transects, and formal interviews with the provincial government policy makers, planners and field officers, particularly to learn more about opportunities to improve subsistence garden productivity. Community-level consultation was centred on the villages around Port Resolution, which are both subsistence farming and fishing communities. In most cases, the women and men were consulted separately, due to the strong gender division still prevalent in traditional culture. This approach secured a more equitable research process and gave the women, in particular, a chance to voice their concerns and opinions.

A common theme through these consultations, amongst both men and women, was the importance of food and fibre production to the well-being of Tanna society. However, it was also considered one of the most significant sources of pressure on the island's habitats. The communities fully appreciated the tight nexus between food production and forest and reef health and customary management. For example, taboo periods were not being honoured like they were in the past, and people are using the forests and reefs even if there is a taboo in place. Additional concerns were raised about 
diminishing fallow periods and degrading performance of traditional cropping systems. Women, specifically, raised a broader set of socio-economic concerns, associated with water, sanitation and health (WASH concepts). Discussions on potential solutions focused on developing hybrid approaches to natural resource management, where the traditional nakamal (the 'meeting place') way of decision making (Lindstrom, 1982) is augmented through use of relevant governance instruments, such as community conservation areas backed by formal local by-laws. Testing new crop types and introduction of more livestock was also commonly put forward as a solution to help maintain food productivity given changing climate conditions and pressure on reef fisheries. In the village of Port Resolution, recent coastal erosion presented a threat to school buildings, which led to suggestions of seawall construction being touted, however, given the significant costs associated with construction and maintenance and the relatively low (and future) costs of retreating, these types of solutions were not further pursued.

\section{The study area}

Tanna is an island in the southern Vanuatu province of Tafea (Figure 1). It covers 58,793 hectares (ha) and has a population of approximately 32,280 (Vanuatu National Statistics Office, 2009). The island's population is predominantly village-based, living in traditional housing in an agrarian subsistence-based economy, and strongly identifying along tribal affiliations. Tanna is often referred to as the stronghold of kastom - pronounced 'custom' and loosely translating as such, but further encompassing a broader range of meanings that include the arrangement of private relations, social and economic systems, ways of being and activities and practices associated with managing the landscape. Tanna is a place where people still know and revere traditional songs, can trace their lineage, and organize and participate in kastom rituals, community decision-making processes and ceremonies. Tanna is regarded as an example of how kastom and modernity can coexist (Lindstrom, 1982, 2011). However, common to many Pacific islands, these cherished customary practices are eroding under the influence of 'western' economic systems and philosophical traditions, such as monetary exchange, economic specialization and individualized expression (Brosi et al., 2007; Nalau, Becken, Schliephack, et al., 2018).

The well-being of virtually all of the population on Tanna depends on a combination of subsistence farming, animal husbandry, and artisanal fishing for sustenance and non-food product harvesting (Vanuatu National Statistics Office, 2009). The farming system typically comprises three components: (i) a shifting cultivation system; (ii) a perennial plantation cultivation system; and (iii) a forest and aboricultural system (Blanco, Pascal, Ramon, Vandenbroucke, \& Carrière, 2013; Clarke \& Thaman, 1993; Thaman, Clarke, Manner, Decker, \& Ali, 1993). In the shifting cultivation component

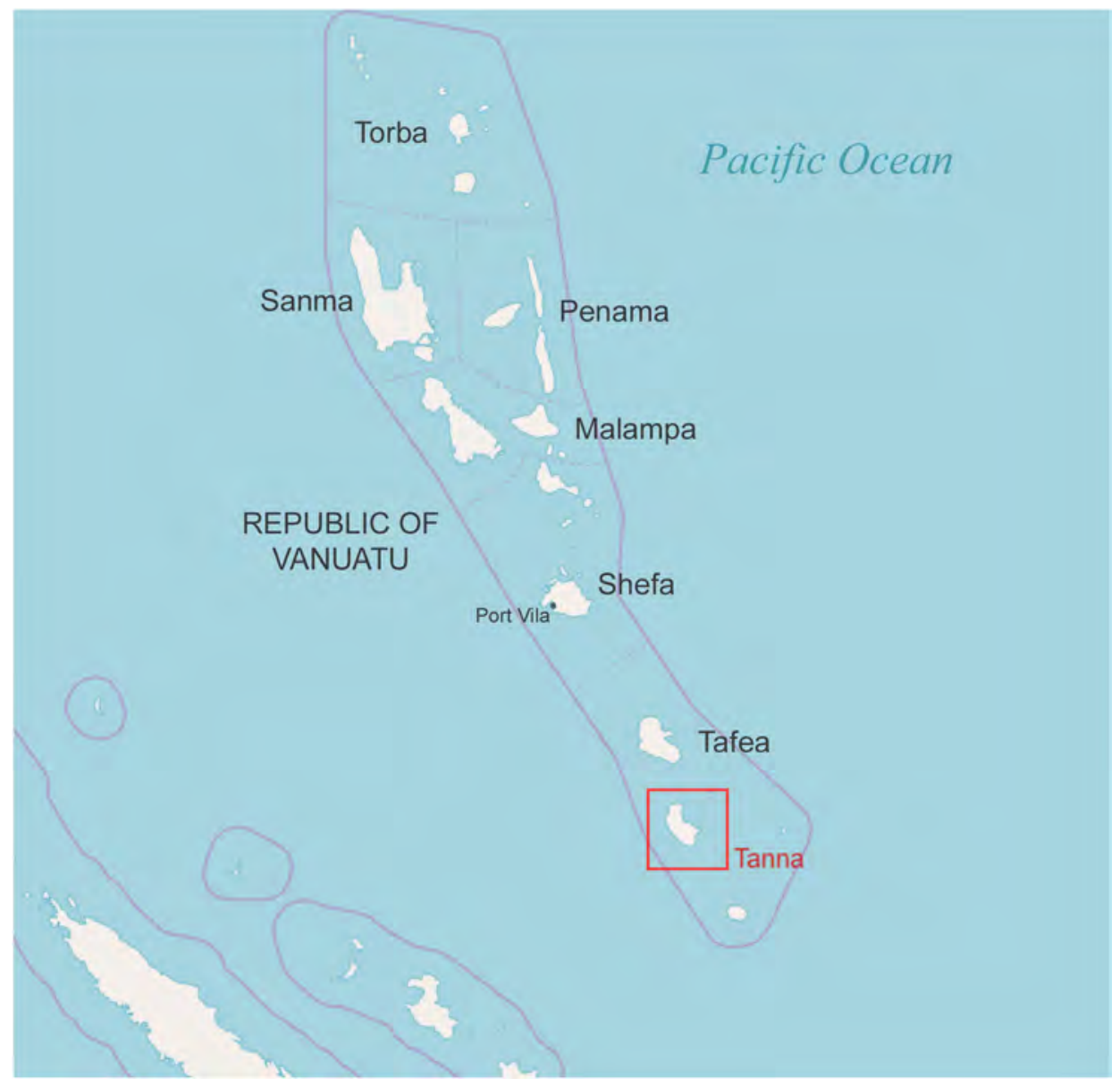

Figure 1. Location of Tanna in the Republic of Vanuatu. 
(that which most closely relates to traditional subsistence gardening), each family slashes and burns secondary forest in two to five locations per year to grow root vegetables, such as taro, yam, manioc (cassava), and banana. Then, having depleted the soil's fertility, the family leaves the land fallow, allowing secondary forest regrowth to start the cycle again (Mackey et al., 2017). The traditional shifting cultivation crops are today being supplemented by recently-introduced peanuts and sweet potato. However, as we discuss further below, it has become apparent in recent years that a growing population and increasing demand for food has resulted in a decrease in the length of time a plot typically remains fallow and that this is most likely the cause of what is a widely substantiated view that subsistence farming yields are declining. The perennial cultivation system constitutes the main source of any cash income for families; mostly comprising 'cattle under coconut' (Lamanda, Malézieux, \& Martin, 2006), cacao, coffee and sandalwood. Large trees, such as breadfruit, are often left standing amongst the garden plots, and new productive fruit, nut and fig trees are often planted for their economic and cultural value. The productivity of this subsistence system and integrity of the adjoining tropical forests are at the centre of a complex web of interdependencies that have an impact on overall village community resilience, within which climate change is a significant factor (Barnett, 2001, 2011) (Figure 2).

Broader economic opportunities and employment specialization is limited. Although the indigenous inhabitants (NiVanuatu) face persistent poverty (in terms of income and risk indices), which is linked to increasing environmental and resource pressures, specifically the rural $\mathrm{Ni}$-Vanuatu have remained relatively immune from poverty in terms of destitution and food insecurity, due to continuation of widespread subsistence gardening and fishing activities, and access to customarily-managed land (Asian Development Bank, 2003; Gerbeaux, Kami, Clarke, \& Gillespie, 2007). Where households receive cash incomes, the main expenditure is on rice, salt, soap, and school fees.
Under IPCC climate change scenarios Tanna will continue to experience sufficient within-island climatic variability to require subtly different adaptation actions between the north and the south of the island, and between the coast and the uplands, particularly with respect to promoting the resilience of subsistence farming and its corollary, forest management (IPCC, 2014; Mackey et al., 2017, pp. 46-53). In addition to rising temperatures, projections suggest an overall wetting trend (largely associated with summer rainfall), an increase in tropical cyclones under El Niño conditions, sea level rise, warming sea surface temperatures, and ocean acidification, resulting in highly-stressed corals. (Being a volcanic island, rather than an atoll, Tanna is not at existential threat of being overwhelmed by sea level rise.) While climate change presents serious threats to Tanna communities and habitats, it is important to consider these pressures in the context of ongoing environmental changes and the drivers of these changes, particularly population growth and land use change (deforestation) (Mackey et al., 2017, pp. 54-56). This combination of climate-related and geological risks, low income, poor public services, and low capacity render Vanuatu as the most at-risk nation to natural hazards in the world (United Nations University, 2015).

\section{Intervention programmes}

Based on formal and informal community and stakeholder consultation over the period of the PEBACC project (see supplementary material), we developed a series of interlinking EbAs to address identified risks to the resilience and adaptive capacity of village communities of Tanna. For the purposes of our case study, we determine resilience to mean the capacity of a system (in this instance, Tanna village communities) to respond to a trend change or disturbance and still retain its core functions (community wellbeing) in a steady state. Adaptive capacity infers an ability of a system to adjust to external changes and yet still prosper (Jones, 2019). Specific risks arise from demographic and climate-related pressures on the condition of the coral reef and on the close-coupled tropical forest

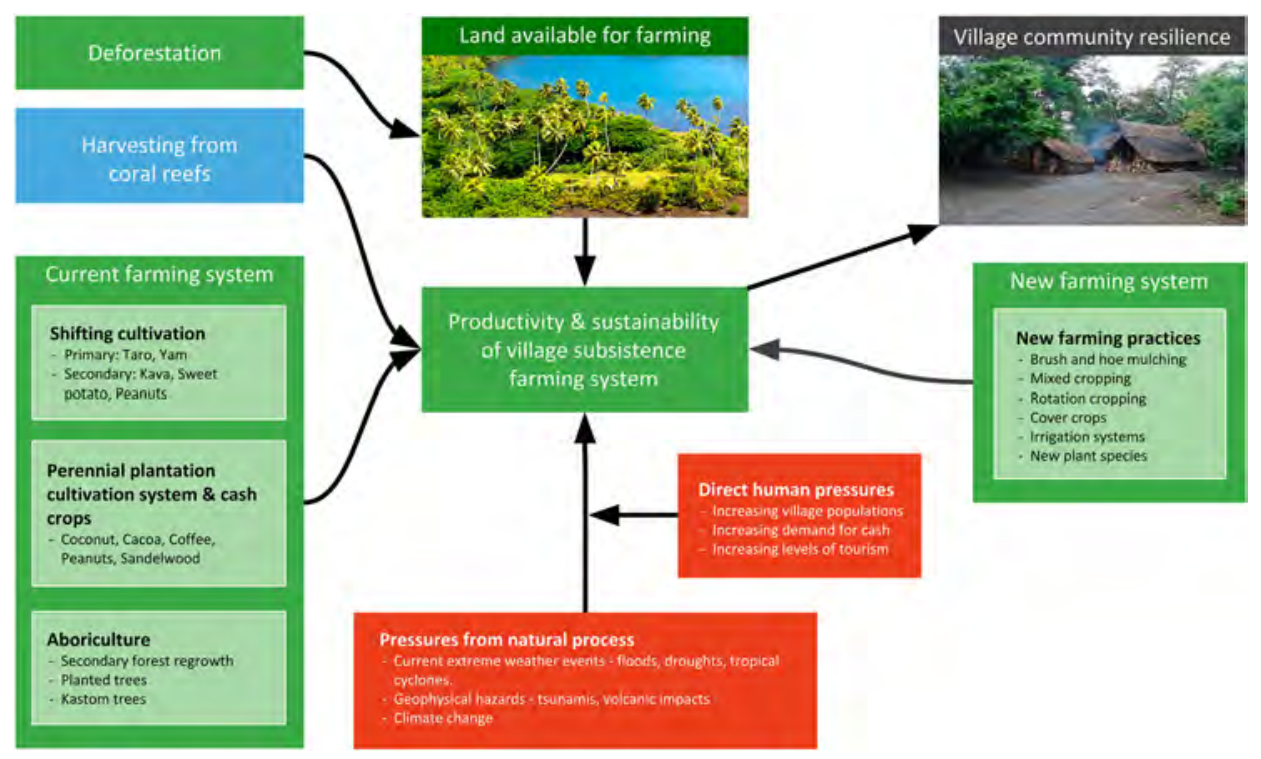

Figure 2. Factors influencing the productivity and sustainability of village subsistence farming systems. 
and subsistence garden system. The proposed programme of works is based on two interlinked projects, which can be implemented either in coordination with each other, or as stand-alone projects.

(i) Implementation of demonstration garden plots and an agricultural extension programme to drive new behaviours and innovation in subsistence gardening, an upgrade of the Tanna's regional government plant nursery, and implementation of a community radio station to assist with the promotion and engagement of the community in the demonstration plots.

(ii) Technical and logistical support for the establishment of a series of community-based conservation areas (marine and terrestrial) to formalize and support reef and tropical forest conservation efforts.

Individually, the projects are representative of interventions along the spectrum from 'pure' $\mathrm{EbA}$, such as coral reef conservation for coastal protection and improving the sustainability of fish harvests, to 'hard' interventions, such as the installation of equipment to run a community radio station. However, in toto, the programme is firmly in the realm of $\mathrm{EbA}$ - with its key focus on habitat protection and restoration and enhancing ES flows.

\subsection{Improving productivity of subsistence gardens}

One of the higher return policy interventions for improving rural well-being and resilience is stimulating innovation in the sectors from which the rural poor derive their livelihoods (Weber, 2012, p. 84). Ninety-eight percent of all Tanna households undertake some form of subsistence food production, mostly root vegetables and fruits from household gardens, animal husbandry (pigs and chickens), and in coastal areas, fishing is common (Vanuatu National Statistics Office, 2009). Food production capacity can be increased by expanding the land available for farming, but this comes at the expense of alternative ecosystem types, principally kastom forest, or by increasing fishing effort, that can result in over-harvesting of fish from the fringing coral reefs. To avoid such impacts on forest and reef ecosystems, modified farming systems and practices are needed, which can improve soil fertility and sustain high productivity and crop diversity in existing garden areas. Projected climate change impacts are also an important concern, as rising temperatures will push the optimal thermal envelope for highyield staples, such as taro, to higher elevations and to the south - areas that are currently under widespread kastom forest tenure. The northern end of the island is currently drier and future climate may lead to increases in seasonal droughting, even if annual rainfall increases (Mackey et al., 2017).

Locally-reported falling yields from these gardens present a significant risk to food security and local habitats (Mackey et al., 2017). This fall in productivity is also supported by observations across Vanuatu by Fleming (2007), who reports a linear trend in falling productivity of $-2.95 \%$ per annum (total factor productivity) between 1970 and 2002. The pressure on Tanna's subsistence farming system from direct human pressures is accentuated by the relatively small area of high-quality arable land available. We also have empirical evidence that there has been an increase in the area of cropped versus fallow land (i.e. natural forest regrowth), contributing to a marked decrease in fallow periods when compared with traditional practices (Mackey et al., 2017). Community interviews highlighted that some villagers are experiencing declining taro production, a decrease in soil fertility, and competition between growing food for cash and subsistence, along with increasing cultivation intensification and a loss of tree cover. Some communities also report clearing of primary forest for taro production as a response to increasing food demand and declining soil productivity.

Improved productivity can potentially be achieved through changes in management of subsistence gardens, such as incorporating new crop varieties (climate-resilient crops) and growing techniques, localized irrigation, improving soil fertility, introducing higher value crops, and diversifying the local economy (Mael, 2013). Demonstration farming plots and agricultural extension programmes have proven to be effective in encouraging innovation and improving farmer welfare and are a key strategy in the Vanuatu NSDP (Objective ECO 3.4) (James et al., 2011; Moser \& Barrett, 2006; Nakano, Tsusaka, Aida, \& Pede, 2018; Republic of Vanuatu, 2016b; Suvedi, Ghimire, \& Kaplowitz, 2017). As farmers make decisions based on uncertain benefits and uncertain costs, demonstration plots can provide a level of assurance to support individual farmers' innovation, reducing exposure to risk of failure, hunger, loss of income or indebtedness (Adesina \& Zinnah, 1993, p. 297; Eklund, 1983; Marglin, 1965). Community social structures already provide some degree of risk mitigation (Clifton \& Wharton, 1971), but there is a generally slow adoption of new technologies for subsistence farming, without support. In addition to risk exposure, knowledge constraints, input availability and conformity effects are also significant factors in low subsistence farming innovation (Clifton \& Wharton, 1971; Dercon \& Christiaensen, 2011; Moser \& Barrett, 2006; Nyyssölä, Pirttilä, \& Sandström, 2014; Weber, 2012).

The early impact of extension programmes has been shown to be high and technology diffusion, through neighbourly connections, has proven to be persistent and continues indefinitely, making extension programmes a cost-effective enterprise (Krishnan \& Patnam, 2014, p. 308). They can foster a culture of 'learning by doing' (Conley \& Udry, 2010; Foster \& Rosenzweig, 1995) and peers can be encouraged when they observe good results through 'social learning', or emulating others, particularly within the same village or tribe (Foster \& Rosenzweig, 1995). Much of the success of demonstration plots is earned through a propagation of a personal belief that individuals can achieve what their peers can, so having successful neighbours is, unsurprisingly, important, as growers want to see their peers achieve results before adopting the new practice. In general, technology diffusion is more common with nonfood than food crops and with cash crops rather than those produced for household consumption and it is also further influenced by gender, employment, household size, education level, age, land size, and off-farm income (Clifton \& Wharton, 1971; Langat et al., 2013). Notwithstanding, there are obvious challenges to technology diffusion relating to communication and connectivity in remote rural communities, generally. For 
Tanna, these challenges are further complicated by a generalized reluctance to share technology between clans and language diversity present on Tanna (Andrew, Andasua, \& Baynes, 2016; Nehrbass, 2012). Finally, from a communications perspective, community radio has shown to be useful in raising and maintaining awareness, but is insufficient to convince people to take up new practices in and of itself (Weber, 2012).

Our project proposes a series of six demonstration garden plots (one in each sub-island administrative district), each supported by a salaried local extension officer, with budget for equipment, a vehicle and botanical needs, a salaried central project officer, with budget for an office, equipment and a vehicle, and a community radio station, including programme creation consultancies and equipment, broadcast technology and programming support, to drive engagement with the programme. In addition, to assist in the production and propagation of new plant stock and tree saplings for reforestation and revegetation efforts, a centralized nursery is proposed, at the site where an existing government nursery is currently operating, at Isangel (albeit at a very small scale, currently). We also factor-in an expansion of Tanna's poultry stock, supported by a centralized hatchery and more widespread introduction of poultry into the subsistence garden food systems to increase the protein production capabilities of the land (eggs and meat), to help manage pests, and to increase nitrogen cycling (Dumas et al., 2016). Our budget also includes costs for specialist consultancies for permaculture design, hatchery management, project evaluation, contract management, administrative costs, and all recruitment. All our cost are based on estimates from expert opinion in the international development community, local forestry and agriculture officers, and informal quotations from service providers in Vanuatu and Australia. Our five-year project budget is set out in Table 1, which accounts for inflating prices over the project timeline at 3.5\% per annum.

\subsection{Community-based conservation}

Vanuatu law relating to customary ownership of natural resources is based on the fundamental concept, enshrined in the Constitution (Chapter 12, Article 71), that all land and in-shore reefs are the inalienable property of the Ni-Vanuatu (Amos, 2007). The Ni-Vanuatu of Tanna have a long history of sustainable natural resource management and have developed a range of kastom practices to protect and conserve Tanna's ecosystems (Lindstrom, 1982, 2011; Regenvanu, Wyatt, \& Tacconi, 1997). However, it is also evident these claims of sustainability need to be qualified, as coastal fisheries are under threat, garden productivity is falling and deforestation continues (Fleming, 2007; Mackey et al., 2017). In support of customary management, the Vanuatu Environmental Management and Conservation Act 2002 allows for establishment of Community Conservation Areas (CCA) - the key conservation tool in Vanuatu legislation. To be formalized, a CCA must be registered with one of the appropriate Vanuatu government departments. Creating the CCA must follow an established procedure, which allows for community consultation, biodiversity audits, community approval of a management plan, notification of neighbouring communities and support from both the island Council of Chiefs and the provincial government. CCAs may be of any size, marine or terrestrial, privately-, community- or cooperatively-owned and managed, and can support local practices by allowing for the sustainable harvesting of resources, such as fish, timber and non-timber forest products. The community-based conservation component of our proposal aims to develop Tanna's formal natural resource management capacity in a way that is based upon kastom practices and Vanuatu legislation.

Whilst this legislatively-established procedure provides checks and balances to creating equitable, sustainable, and worthwhile conservation areas, the technical, managerial and logistical demands create barriers to their establishment. Our project proposal establishes coordinating staff and supports the technical, consultative and evaluation aspects of establishing a series of marine and terrestrial CCAs on Tanna to support the conservation of the two most important ecosystem types: coral reefs and tropical rainforests. Once established, it is expected that each CCA will be self-managed by communities with sufficient knowledge and capacity to best ensure their ongoing value to the local community. This capability will be primarily achieved through the establishment of a community ranger programme, which will provide for a network of local community rangers as implementation managers for each area. The rangers will be provided with a wage, resources, responsibilities, training and mentoring. Community ranger programmes have demonstrated success in achieving conservation and habitat management and restoration objectives in a wide range of societal settings from Australia to Namibia (Australian Government, 2018; Stuart-Hill, Diggle, Munali, Tagg, \& Ward, 2005). Numerous local benefits can flow from community ranger programmes, including generating local, culturally meaningful, employment (which can encourage younger people to stay on-country on Tanna), building community capacity, and enabling a mechanism for applying traditional knowledge to be integrated into land management (Moritz, Ens, Potter, \& Catullo, 2013).

While formalization of the CCAs is an option, it is not a central focus. The key is to establish the capacity for effective community-based resource management, with or without registration. The formalization process has been subject to

Table 1. Project budget for six demonstration plots and extension officers, tree nursery expansion and community radio station (US\$).

\begin{tabular}{|c|c|c|c|c|c|c|c|}
\hline Project component & Year 1 & Year 2 & Year 3 & Year 4 & Year 5 & Total (5 years) & Ongoing costs (per annum) \\
\hline Tree nursery & 101,600 & 50,301 & 52,062 & 53,884 & 55,570 & 313,616 & 42,350 \\
\hline Demonstration plots, poultry management, engagement officers & 346,060 & 199,921 & 206,440 & 213,187 & 226,482 & $1,192,089$ & 153,600 \\
\hline Sub-total & 447,660 & 250,222 & 258,502 & 267,071 & 282,252 & $1,505,705$ & 195,950 \\
\hline Community radio station & 654,880 & 71,899 & 73,485 & 75,162 & 79,933 & 955,360 & 70,000 \\
\hline Totals & $1,102,540$ & 322,121 & 331,987 & 342,233 & 361,985 & $2,461,065$ & 265,950 \\
\hline
\end{tabular}

${ }^{\mathrm{a}}$ Ongoing costs are represented here in relation to scenarios described in the Results section and in the analysis, are subject to $3.5 \%$ inflation per annum. 
significant criticism on the basis that it focuses on the interests and the skill sets of the international NGO community, which benefits from being seen establishing formal conservation, without obligation for ongoing resourcing at the expense of local communities who risk the loss of control of their resources with no ongoing benefits (Hickey, 2008; Ruddle \& Hickey, 2008).

\subsubsection{Forest-based conservation}

The role of forest assets to the well-being of the Ni-Vanuatu is recognized in the Vanuatu Forest Policy (Department of Forests, 2011), however, there remains a gap between policy intent and implementation. As fallow periods shorten, intensification of gardening efforts leads to clearing of remnant trees in the agroforestry system and in addition, large areas of primary forest are now at risk (Mackey et al., 2017). There are significant benefits from retaining primary forest adjacent to subsistence gardens. Forests provide fuel-wood and non-wood forest products, improve soil stability and fertility, and subsistence garden forest cover provides shade and microclimatic buffering from extreme weather events (Harrison, Karim, Alauddin, \& Harrison, 2016). If the extent and connectivity of remnant primary forests cross critical thresholds, these benefits will diminish, and further downward pressure is placed on subsistence garden productivity. Assisting communities with the protection of forest areas as an EbA, implemented through CCAs, can thus reduce the risk of climate change impacts.

\subsubsection{Marine community conservation areas}

Marine protected areas (MPAs) are zone-based, mixed management marine areas, targeted at ensuring sustainability in the management of fisheries and integrity of coastal coral reef ecosystems. Zones can be managed along a spectrum from 'no-visit' and 'no-take' to temporary closures or gear restrictions. Implementation and effective management of MPAs can increase fish diversity and biomass (or at least arrest declines), particularly as they mature, when they can measurably increase local food security (Mascia, Claus, \& Naidoo, 2010). Where mixed zoning includes at least some no-take zones, this increases biomass and take zones can benefit from spill-over (Lester et al., 2009). MPAs do not necessarily increase coral cover, but can arrest its (often) continued demise in proximity to human settlement (Agardy, Di Sciara, \& Christie, 2011; Mascia et al., 2010). The presence of MPAs has been shown to increase tourism in Vanuatu (Pascal et al., 2015) and there is a strong link between biological success and social success (legitimacy) (Christie, 2004). Customary management systems should be dynamic and evolve adaptively to changing social, political, economic, and cultural conditions (Cinner \& Aswani, 2007). In addition, combining the goals, techniques, and institutions of modern fisheries management with customary MPA management can mitigate against failures of current inshore resource management and the vulnerability of customary management institutions to socioeconomic change. Implementation of MPAs can positively affect local environments; firstly, through spill-over effects of biota (Guidetti, 2007) (though these are moderate); and secondly, through knowledge diffusion and so-called 'copycat entrepreneurship'
Table 2. Project budget for establishment of community conservation area logistical and technological support and management of community ranger programme (US\$).

\begin{tabular}{lcccccc}
\hline Project component & Year 1 & Year 2 & Year 3 & Year 4 & Year 5 & $\begin{array}{c}\text { Total (5 } \\
\text { years) }\end{array}$ \\
\hline $\begin{array}{c}\text { Community rangers } \\
\text { programme }\end{array}$ & 44,800 & 34,776 & 35,993 & 37,253 & 38,557 & 191,379 \\
$\begin{array}{l}\text { Community } \\
\text { conservation area }\end{array}$ & 24,500 & 25,358 & 26,245 & 27,164 & 28,114 & 131,381 \\
$\begin{array}{l}\text { support } \\
\text { Totals }\end{array}$ & 69,300 & 60,134 & 62,238 & 64,417 & 66,671 & 322,760
\end{tabular}

(UNDP, 2012, p. 11), whereby the successful management model is replicated through the region.

Conservation of Tanna's coastal coral ecosystem and the sustainability of reasonable fishing yield are critical for coastal communities, not only in terms of food security, but also in providing significant benefits in terms of raw materials, coastal protection and disturbance moderation (Mackey et al., 2017). In addition, a healthy reef ecosystem will likely be a key habitat type for visitation in the developing tourism industry in Tanna. Though MPAs are found elsewhere in Vanuatu, particularly on Efate, they are not widely used on Tanna, suggesting institutional and capacity barriers to their establishment. Vanuatu currently has 18 formal MPAs registered through the CCA process (Marine Conservation Institute, 2018). Their extents range from 30 to 0.11 ha, though most extents are unreported. None are registered for Tanna. Informal MPAs (not registered through Vanuatu legislation) also exist. The authors are specifically aware of locally-formulated MPAs in the Cook's RockPort Resolution region of Tanna, though by their nature, there is no data on boundaries and any management measures.

Our programme budget for CCA logistical and technical support and the community ranger programme is set out in Table 2, which accounts for inflating prices over the project timeline at $3.5 \%$ per annum. The programme budget would account for the implementation of one new CCA each year for the five years of the project, each establishing 10 ha of forest and 2 ha of MPA, managed by two employed community rangers each. Our budget includes line items for salaries for community rangers and a ranger coordinator (plus vehicle), costs associated with setting-up and supporting management committees and technical consultancies for biodiversity audits and mapping services. Again, our costs are based on estimates from expert opinion in the international development community, local forestry and agriculture officers.

\section{Methodology}

\subsection{Method of assessment}

Social benefit-cost analysis (SBCA) compares the relative value of benefits and costs of a project under consideration, over time, to determine the project's economic value on its own merits, from a broad, all-of-society perspective (Boardman, Greenberg, Vining, \& Weimer, 2017; Leary, 1999). Various metrics can be computed for project assessment: firstly. the 'net present value' (NPV) is the total present value benefit minus the total present value cost for the project as a whole; secondly, the 'benefit-cost ratio' (BCR) is the ratio of the 
present value benefits to present value costs (this determines a 'return on investment' for each unit of present value cost incurred); and thirdly, the internal rate of return (IRR), which reflects the rate of 'growth' in the value of the investment (computed by determining the discount rate at which the NPV of a project equals zero). In our case study we use NPV and benefit cost ratio metrics. IRR is considered inappropriate in the context of grant-funded programmes, where benefits are predominantly social in nature.

The economic feasibility of a project is assessed by determining whether the social benefits are greater than the costs, including the opportunity cost (i.e. whether the private capital could achieve greater returns elsewhere) (Hernández et al., 2006). In this instance, we do not attempt to determine the opportunity cost as the entire project would be likely funded by an external large-scale funding body, purely for broad, social benefit.

Social costs and benefits can make use of economic valuations of changes in ES delivery. In this study we widely deploy ES value estimates either using coefficients established by Mackey et al. (2017), which are predominantly based on the The Economics of Ecosystems and Biodiversity (TEEB) valuation database (van der Ploeg \& de Groot, 2010), or from references in the published literature. In this case study we estimate gains and losses in ES value from: (i) productivity changes in subsistence gardens; (ii) extent changes of tropical forests; (iii) changes in value of fisheries; (iv) changes in value of coastal protection from the conservation of coral reefs; and (v) changes in value of tourism, facilitated through the establishment of marine CCAs. To establish an appropriate value for benefit transfer to Tanna, we first used Vanuatu-specific valuation studies, where available $(n=$ 2). When not available, we applied the most appropriate filters to the TEEB database to derive values for Tanna (using a median value, if there was more than one value from the database). Finally, for the annual value of subsistence gardens we used Anderson's (2006) estimates of the value of customary-managed land for subsistence food production in Papua New Guinea (culturally, also Melanesian), adjusted to 2016 values and further adjusted to take account of lower GDP per capita (purchasing power parity) for Vanuatu. Anderson's study calculated the replacement value, at local market prices, of produce growth in subsistence gardens.

Through this process we established per hectare, per year ES values for subsistence gardens, tropical forests and coastal coral reefs by summing the appropriate values across as many of the individual ESs we could establish values for. (There was only a single value for food, for subsistence gardens.) We recognize there are gaps in some values (biological control value for forests being an important one), due to a paucity of data, particularly for non-market values associated with cultural connections to country. Cultural ES values can be difficult to value economically and arguably do not lend themselves well to benefit transfer due to their highly-localized nature and the potential for cultural relationships to be non-negotiable (Pröpper \& Haupts, 2014; Venn \& Quiggin, 2007). Whilst gaps in ES values and difficulties in establishing some cultural ES values inevitably leads to under-estimation of social benefits, conversely, when deciding between implementation of competing projects, economic valuation is only one consideration and cultural values can, and perhaps should, be assessed more qualitatively. Table 3 provides a qualitative summary of trend losses and gains in ES value and ecosystem extent associated with the proposed projects. All values are adjusted to 2016 values, using World Bank data. Full details of our valuation and extent change methodologies are in the Supplementary Materials.

We assess a range of different scenarios for the subsistence gardens project. Our base case is a 5-year funding timeframe, whereby households engaged in the programme, either directly by the extension officers or through technology diffusion, are doubling the productivity of their gardens over a 25-year period. The increases in productivity follow a logistic growth curve, with slow growth at first, accelerating through the middle years (peaking in growth in year 12) before approximately levelling-out after year 23 and remaining indefinitely at a near-doubled rate. Components included in this scenario

Table 3. Summary of gains and losses in ecosystem service value or ecosystem extent.

\begin{tabular}{|c|c|c|c|}
\hline & $\begin{array}{l}\text { Demonstration plots, farming extension, community } \\
\text { radio }\end{array}$ & Community conservation area (CCA) (marine) & $\begin{array}{l}\text { Community conservation } \\
\text { area (CCA) (forest) }\end{array}$ \\
\hline $\begin{array}{l}\text { Value (US\$ ha } \mathrm{hr}^{-1} \mathrm{yr}^{-1} \text { ) } \\
\text { and extent (ha) of } \\
\text { subsistence gardens }\end{array}$ & $\begin{array}{l}\text { Value increases as a logistic function as extent of land } \\
\text { under modified practices increases (which is } \\
\text { proportional to the number of households engaged in } \\
\text { the programme). For those households not engaged, } \\
\text { the value falls as productivity is generally falling in } \\
\text { Vanuatu. Total area under cultivation rises in-line with } \\
\text { population growth, but this rise is suppressed by the } \\
\text { rate of increase in productivity }\end{array}$ & - & - \\
\hline $\begin{array}{l}\text { Extent of tropical forests } \\
\text { (ha) }\end{array}$ & $\begin{array}{l}\text { Extent of tropical forest generally reduces due to } \\
\text { existing deforestation. The rate of deforestation is } \\
\text { dependent on the level of productivity increase on } \\
\text { cultivated area under modified practices }\end{array}$ & - & $\begin{array}{l}\text { Extent of tropical forest } \\
\text { increases in area subject } \\
\text { to CCA }\end{array}$ \\
\hline $\begin{array}{l}\text { Value of fishery (US } \\
\left.\qquad \mathrm{ha}^{-1} \mathrm{yr}^{-1}\right)\end{array}$ & - & $\begin{array}{l}\text { Fishery value increases in a logistic function in area } \\
\text { subject to CCA. Where CCA is not present, the } \\
\text { value of the fishery falls as an inverse log function }\end{array}$ & - \\
\hline $\begin{array}{l}\text { Value of coastal } \\
\text { protection (US } \\
\left.\$ \mathrm{ha}^{-1} \mathrm{yr}^{-1}\right)\end{array}$ & - & $\begin{array}{l}\text { Extreme event moderation value of coral reefs } \\
\text { remains constant in area subject to CCA. Outside } \\
\text { this area, this value diminishes in an inverse log } \\
\text { function }\end{array}$ & - \\
\hline $\begin{array}{l}\text { Value of tourism (US } \\
\left.\qquad \mathrm{ha}^{-1} \mathrm{yr}^{-1}\right)\end{array}$ & - & $\begin{array}{l}\text { Recreational value of coastal coral increases in area } \\
\text { subject to CCA }\end{array}$ & - \\
\hline
\end{tabular}


are: (i) six demonstration plots and extension officers; (ii) one centralized tree nursery; and (iii) a community radio station. We also assess this project without the implementation of a community radio station (this reduces the engagement rate, but not the technology diffusion rate). In addition to our base case scenario, we also modelled the outcomes if the project components could be continually annually refinanced over a 25-year period (for example, from an endowment), using an estimated annual project maintenance cost, subject to a $3.5 \%$ inflation rate (Table 1). For the CCA project we assessed a base case only, where 2 ha of MPA and 10 ha of forest conservation area are established, with 5 years of funding, with benefits assessed over the same 25-year period.

SBCA inevitably entails comparison of costs and benefits that arise at different points in time. To enable meaningful comparison, these costs and benefits are converted into their 'present value' by applying an annual discount rate - the rate at which the value erodes over time. From a societal perspective, the discount rate applied reflects whether society prefers to obtain beneficial outcomes sooner rather than later, society's attitude towards the risk of investments failing to deliver the expected return, and a reflection of the time value of money. Private discount rates for $\mathrm{Ni}$-Vanuatu households will likely be high, as decisions on risks surrounding the variable yields from subsistence gardening of perennial crops and exposure to natural hazards can influence household wealth significantly. However, no consensus exists on which discount rate should be used in relation to ES benefits, nor is there an accepted 'Pacific standard' for application in the region - the majority of finance ministries do not promote a preferred rate (Buncle, 2013). For this study, we selected a centre point discount rate of $10 \%$ that sits at the upper bounds of that recommended by Buncle (2013), which reflects the commonly applied discount rates by analysts for project assessments in the Pacific.

\section{Results}

Under all scenarios, our SBCA demonstrates significant positive NPVs from improving the productivity of subsistence gardens on Tanna. Implementation of community conservation efforts (either marine, terrestrial, or a combination of both) yields a neutral NPV at the centre-point discount rate. Our base case garden improvement analysis indicates an NPV of US\$ 182.6 million (m) (all figures in 2016 US\$ values) at a BCR of 93, when the discount rate $(r)$ is $10 \%$. This assumes that 25-years after project commencement, approximately $32 \%$ of all households in Tanna will be at some stage of a journey of year-on-year productivity improvement, assuming that subsequent technology diffusion occurs after the project ends. (For details of our productivity gains analysis, see Supplementary Materials.) If a supporting radio station is not funded (i.e. the engagement process is less effective), the project still returns a NPV of US\$ $86.6 \mathrm{~m}$ at a BCR of 74 . This assumes at the end of the 25 -year period, only $16 \%$ of all households would be undertaking modified techniques (Table 4).

We also modelled the outcomes if the garden project components could be continually refinanced over a 25 -year period, using an estimated annual project maintenance cost of US\$ 265,950 (with radio station) and US\$ 175,350 (without radio
Table 4. Net present value (NPV) and benefit cost ratio for base case scenario garden improvement (six sites), both with a supporting community radio station and without $(r=10 \%)$.

\begin{tabular}{lccccc}
\hline & \multicolumn{2}{c}{$\begin{array}{c}\text { Subsistence gardens with } \\
\text { supporting radio station }\end{array}$} & & $\begin{array}{c}\text { Subsistence gardens } \\
\text { without supporting radio } \\
\text { station }\end{array}$ \\
\cline { 2 - 3 } $\begin{array}{l}\text { Improvement in } \\
\text { productivity over } 25 \\
\text { years }\end{array}$ & NPV & $\begin{array}{c}\text { Benefit } \\
\text { cost ratio }\end{array}$ & NPV & $\begin{array}{c}\text { Benefit } \\
\text { cost ratio }\end{array}$ \\
\hline $\begin{array}{l}100 \% \text { improvement in } \\
\text { productivity }\end{array}$ & $182,575,159$ & 93 & & $86,654,751$ & 74 \\
$\begin{array}{c}50 \% \text { improvement in } \\
\text { productivity }\end{array}$ & $112,755,934$ & 58 & & $51,188,706$ & 45 \\
$\begin{array}{c}25 \% \text { improvement in } \\
\text { productivity }\end{array}$ & $73,738,681$ & 38 & & $31,292,990$ & 28 \\
\hline
\end{tabular}

station) (Table 5), inflating over time at 3.5\%. Being continually supported over such a period increases the reach of the engagement aspects of the project. If supported by a community radio station, over 25-years, all Tanna households could be reached by year 17 and annual funding for the demonstration plots and agricultural extension officers could cease, as any annual additional households (forming as a result of population growth) could be engaged within our modelled bounds of unsupported technology diffusion. In such a scenario, the NPV of the project is US\$ $448.8 \mathrm{~m}$ at a BCR of 122 for a doubling of productivity. In the absence of a radio station, funding for the demonstration plots and extension officers must continue through the 25-year period. In this instance the NPV is US\$ $240.8 \mathrm{~m}$ at a BCR of 91 .

We performed a sensitivity analysis by adjusting both the discount rate from $10 \%$ to $15 \%$ and $3 \%$ and the rate of increase in productivity of the subsistence gardens over 25-years from $100 \%$ to $50 \%$ and $25 \%$. Where $r=15 \%$, progression towards a $25 \%$ increase in productivity and no implementation of a community radio station, under the fixed 5-year project timeframe (i.e. the project's least favourable scenario), the project still returns a favourable NPV of US\$ $15.4 \mathrm{~m}$ with a BCR of 18 . The full outputs of our sensitivity analyses are in Tables 6 and 7.

For implementation of the CCA programme (marine and terrestrial) we estimate a NPV of US\$ 3275 with a BCR of 1.01 , where a $10 \%$ discount rate is applied. This is based on programme costs from Table 2 and implementation of 10 ha of tropical forest and 2 ha of coral reef per year protected under CCA status and employment of 10 community rangers. Where $r=15 \%$, the NPV and BCR are US\$ $-53,218$ and 0.75

Table 5. Net present value (NPV) and benefit cost ratio for garden improvement (six sites), both with and without a supporting community radio station with ongoing programme funding (25-years) ( $r=10 \%)$.

\begin{tabular}{lccccc}
\hline & $\begin{array}{c}\text { Subsistence gardens with } \\
\text { supporting community } \\
\text { radio station }\end{array}$ & & \multicolumn{2}{c}{$\begin{array}{c}\text { Subsistence gardens } \\
\text { without supporting } \\
\text { community radio station }\end{array}$} \\
\cline { 2 - 3 } Demonstration plots & NPV & $\begin{array}{c}\text { Benefit } \\
\text { cost ratio }\end{array}$ & NPV & $\begin{array}{c}\text { Benefit } \\
\text { cost ratio }\end{array}$ \\
\hline $\begin{array}{c}100 \% \text { improvement in } \\
\text { productivity }\end{array}$ & $448,786,430$ & 122 & & $240,761,777$ & 91 \\
$\begin{array}{c}50 \% \text { improvement in } \\
\text { productivity }\end{array}$ & $266,539,576$ & 73 & & $139,596,089$ & 54 \\
$\begin{array}{c}25 \% \text { improvement in } \\
\text { productivity }\end{array}$ & $166,677,409$ & 46 & & $83,129,266$ & 32 \\
\hline
\end{tabular}


Table 6. Sensitivity analysis of benefit cost ratio for implementation of garden improvement programme (six sites) for five-year project timeline, both with a supporting community radio station and without.

\begin{tabular}{|c|c|c|c|c|c|c|}
\hline \multirow[b]{3}{*}{ Demonstration plots } & \multirow{2}{*}{\multicolumn{3}{|c|}{$\begin{array}{c}\text { Subsistence gardens } \\
\text { with supporting } \\
\text { community radio } \\
\text { station } \\
\text { Benefit cost ratio }\end{array}$}} & \multirow{2}{*}{\multicolumn{3}{|c|}{$\begin{array}{c}\text { Subsistence gardens } \\
\text { with no supporting } \\
\text { community radio } \\
\text { station } \\
\text { Benefit cost ratio }\end{array}$}} \\
\hline & & & & & & \\
\hline & $\begin{array}{c}r= \\
3\end{array}$ & $\begin{array}{r}r= \\
10\end{array}$ & $\begin{array}{r}r= \\
15\end{array}$ & $\begin{array}{c}r= \\
3\end{array}$ & $\begin{array}{r}r= \\
10\end{array}$ & $\begin{array}{r}r= \\
15\end{array}$ \\
\hline $\begin{array}{l}100 \% \text { improvement in } \\
\text { productivity }\end{array}$ & 248 & 93 & 51 & 192 & 74 & 41 \\
\hline $50 \%$ improvement in productivity & 152 & 58 & 32 & 113 & 45 & 26 \\
\hline $25 \%$ improvement in productivity & 99 & 38 & 21 & 70 & 28 & 16 \\
\hline
\end{tabular}

Table 7. Sensitivity analysis of benefit cost ratio for implementation of garden improvement programme (six sites) with a supporting community radio station and without, with ongoing programme funding ( 25 years).

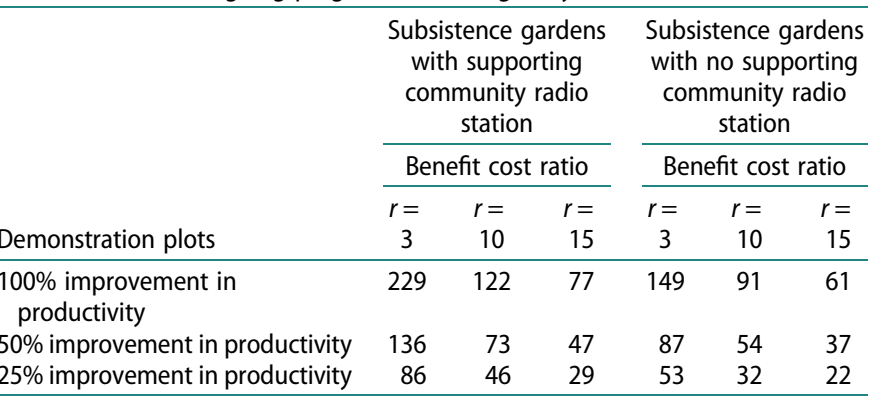

respectively, whilst where $r=3 \%$ the NPV is US\$234,663, with a BCR of 1.79 (see Table 8).

As it is a key variable, in the CCA project, we performed a sensitivity analysis on the social benefit derived from tropical forests by adjusting the per hectare per year value by multiples of 1.5 and 0.5 . For the higher value, the project returns positive BCR for all discount rates. For the lower value, the project returns negative BCR for all discount rates, however, where $r=3 \%$, the NPV is only marginally negative (US\$ $-13,025)$. The full outputs of this sensitivity analyses are in Table 9.

Table 8. Net present value (NPV), benefit cost ratio and sensitivity analysis for implementation of community conservation area (logistical and technical support) and management of community ranger programme over a five-year time line.

\begin{tabular}{|c|c|c|c|c|c|c|}
\hline & \multicolumn{2}{|c|}{$r=10$} & \multicolumn{2}{|c|}{$r=3$} & \multicolumn{2}{|c|}{$r=15$} \\
\hline & $\begin{array}{l}\text { NPV } \\
\text { (US\$) }\end{array}$ & $\begin{array}{l}\text { Benefit } \\
\text { cost } \\
\text { ratio }\end{array}$ & $\begin{array}{c}\text { NPV (US } \\
\$)\end{array}$ & $\begin{array}{c}\text { Benefit } \\
\text { cost } \\
\text { ratio }\end{array}$ & $\begin{array}{c}\text { NPV (US } \\
\$)\end{array}$ & $\begin{array}{c}\text { Benefit } \\
\text { cost } \\
\text { ratio }\end{array}$ \\
\hline $\begin{array}{l}\text { Community } \\
\text { conservation } \\
\text { project }\end{array}$ & 3275 & 1.01 & 234,633 & 1.79 & $-53,218$ & 0.75 \\
\hline
\end{tabular}

Table 9. Sensitivity analysis of benefit cost analysis for value of forests in community conservation areas. (No change in the value of coastal coral reef values.)

\begin{tabular}{lccc}
\hline & $r=3$ & $r=10$ & $r=15$ \\
\hline $150 \%$ baseline value of forest (957 US\$ ha $\mathrm{hr}^{-1} \mathrm{yr}^{-1}$ ) & 2.63 & 1.50 & 1.12 \\
$100 \%$ baseline value of forest (638 US\$ ha $\mathrm{yr}^{-1}$ ) & 1.79 & 1.01 & 0.75 \\
$50 \%$ baseline value of forest (319 US\$ $\mathrm{ha}^{-1} \mathrm{yr}^{-1}$ ) & 0.96 & 0.53 & 0.39 \\
\hline
\end{tabular}

\section{Discussion}

Our SBCA implies that climate change adaptation funding targeted at increasing the productivity of subsistence gardens on Tanna returns very significant social benefits over a 25 -year period, suggesting such a programme of works is a good candidate for EbA project funding on Tanna and, arguably, in Pacific SIDS, in general. Increasing the per unit area food productivity of subsistence gardens and encouraging the introduction of new and adaptive permaculture techniques can (i) help communities adapt to changes to crop growing temperature envelopes, more extreme weather events, and degradation of in-shore reefs; (ii) insure against worsening food insecurity from falling yields and population growth; and (iii) take advantage of co-benefits (positive externalities) that include tropical forest cover retention to regulate soil, water, and micro-climate, and protect biodiversity and contribute towards global efforts to sequester carbon. As improvements to productivity can be potentially adopted by all households on Tanna that farm (98\%) and can, through technology diffusion over a long period, continue to be adopted, the social benefits are substantial (see Table 4). In addition, increasing the community capacity to balance formal forest and reef conservation with customary management can provide small, but nevertheless important complimentary social benefit. Implemented altogether, the programme of works can coordinate and support community development and education on Tanna, as well as augment the logistical capacity, effectiveness and reach of both projects (see Figure 3). In addition, the proposed demonstration plots and upgraded nursery could act as convening hubs for training and engagement for similar projects being undertaken by the development community on Tanna. Both these projects align with Vanuatu's NSDP, which sets the course towards national achievement of the SDGs, particularly Environmental Goals 1 (food and nutrition security), 3 (climate and disaster resilience), 4 (natural resource management), and 5 (ecosystems and biodiversity) and Economy Goals and Policy Objective 3 (strengthen rural communities) (Republic of Vanuatu, 2016b).

Though small-scale demonstration plots have been trialled on Tanna, reportedly with some success (Clarke, McNamara, Clissold, \& Nunn, 2019), adoption of modified gardening techniques is likely to face many of the same barriers on Tanna, as have been documented elsewhere, such as aversion to taking new risks, due to the potential for shocks causing crop failure and loss of livelihood, lack of new inputs and education, and conformity affects (Clifton \& Wharton, 1971; Dercon \& Christiaensen, 2011; Moser \& Barrett, 2006; Nyyssölä et al., 2014; Weber, 2012). These risks are salient in the context of Tanna: in 2015, the island was affected by category 5 Tropical Cyclone Pam that damaged vegetation and crops, which was followed immediately by a drought, delaying replanting. In addition, communications and transport links are poor, meaning access to markets, innovative ideas and new inputs is limited. This likely reticence can be mitigated by undertaking bottom-up implementation, embodied in community-based-adaptation approaches (Clarke et al., 2019), together with the longevity of the proposed project (at least 5 years), which will enable results from perennial and annual crops and the benefits 

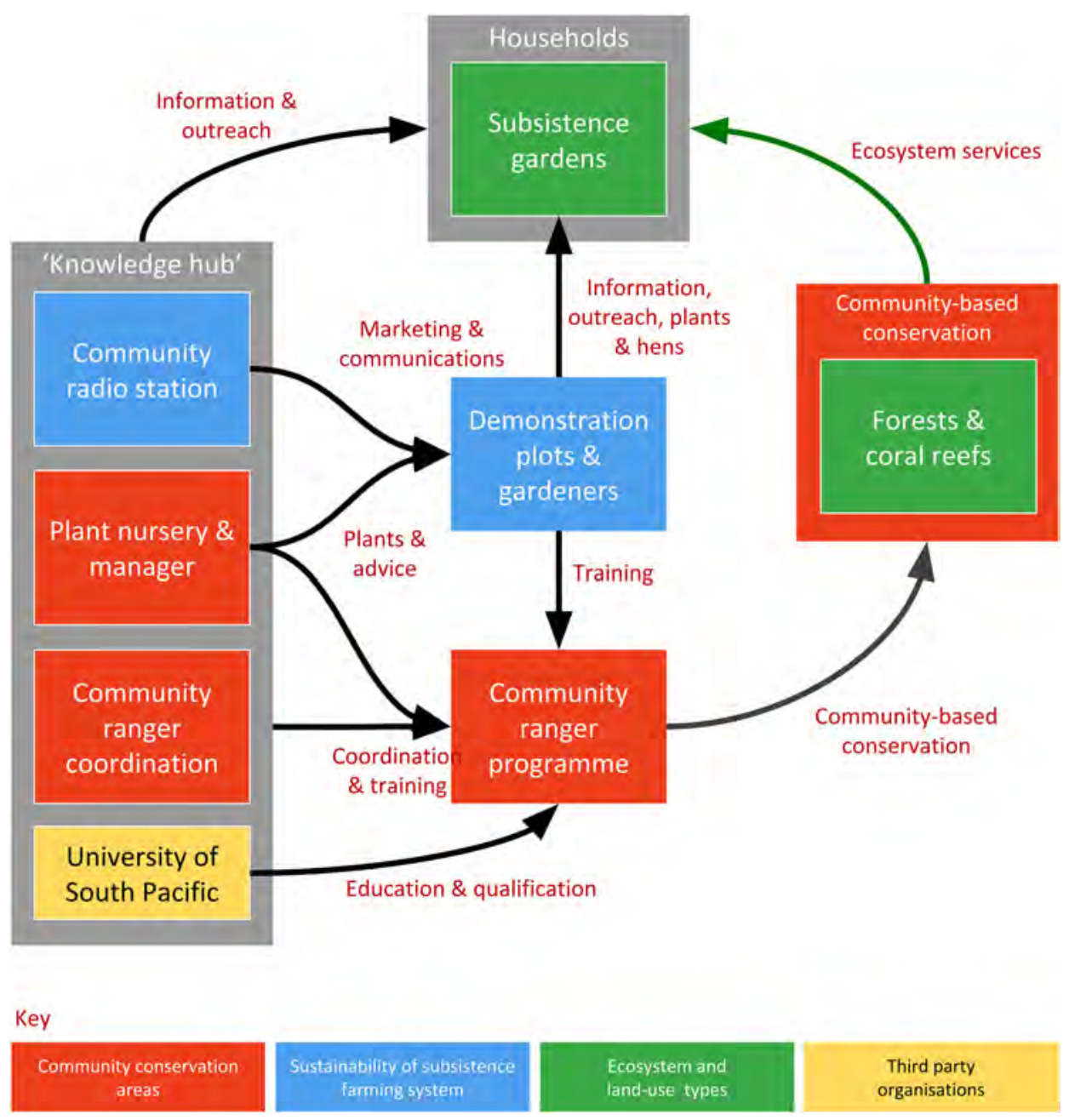

Figure 3. Conceptualization of how the individual project components can function in mutual support.

from new technologies, such as mulching and irrigation, to be demonstrated over multiple growth cycles and, potentially, through El Niño climate oscillations.

Understanding the distributional impacts of the proposed projects is essential to understanding the impact of a project, not just its outputs and outcomes (Asian Development Bank, 2007). No quantitative poverty impact analysis (PIA) has been undertaken to disaggregate which stakeholder groups would likely benefit most from the projects. It cannot be explicitly stated the projects, as proposed, are explicitly propoor. However, a number of demographic attributes of Tanna suggest that we can make at least a qualified judgement that the demonstration plots project, in particular, can benefit indiscriminately and would have positive distributional impacts. Tanna's communities remain relatively homogenous and tribally-based. Tribal affiliation provides entitlements to shelter and customary rights to farming land and forest and marine resources; hence there is no land-owning class that overtly benefits from improved productivity. Nevertheless, this optimism needs to be tempered by the understanding poorer farmers often benefit less from extension programmes due to their propensity to farm smaller plots, be more risk averse, and be less likely to engage in such programmes (Feder, Just, \& Zilberman, 1985). Provided outreach associated with the programme is carefully designed - perhaps even specifically targeting households that are typically hard to reach, or individuals who are marginalized - the impact on poverty reduction should be high. Notwithstanding, a more detailed, quantified PIA, would provide a valuable adjunct to our study.

Undoubtedly, increases in the productivity of the gardens, and a general trend towards economic specialization, economic development and infrastructure investments in Vanuatu, would have an impact on produce prices and mix, and employment wages. However, employment levels and quantities of goods exchanged are starting off a low base - currently, only $12.2 \%$ of Tanna's population 'works for pay', which includes those who are employed, own businesses or produce surplus harvests (fish or vegetables) 'mainly' for sale (Republic of Vanuatu, 2016a). (Ad hoc sale of occasional surplus produce and handicrafts is widespread.) Estimates of the impact on food prices of the proposed projects is beyond the scope of our study, but would also provide a valuable line of enquiry, particularly ex post.

The degree of uncertainty in the projections of future climatic conditions for which adaptation is necessary has an implication on the scale, timing and types of adaptations that are most appropriate. If an adaptation is implemented in a 
way that is inflexible to new information and the future benefits are uncertain (as new conditions may not transpire, or be more extreme than anticipated) assessing the benefits of such an adaptation becomes problematic (Leary, 1999). A benefit-cost framework for judging the welfare of climate change adaptation in light of climatic uncertainty was proposed by Leary (1999): (i) adaptations that entail large irreversible costs, which provide limited present benefits, and which can be delayed until there is greater certainty, should be delayed; conversely (ii) adaptations that might reduce vulnerability in the future, but create present benefits under current conditions, 'are a good place to start' (Leary, 1999, p. 318). Our gardens proposal, in particular, meets these criteria set out by Leary - the costs may be considered significant, but are definitively flexible (even reversible) and each of any component of the proposal generates feasible, demonstrable benefits even if climatic conditions do not change. The flexibility inherent in our gardens project also accounts for changes in socio-economic conditions. For example, a small number of communities in Tanna (the Port Resolution and Whitegrass areas, for example) potentially face significant social, economic and environmental upheaval in the short-term, particularly from increases in tourism visitation and development, and a transition towards a more economically specialized, cash-based economy. For example, the authors are aware of particular potential developments in Port Resolution, including the development of a regional airport and a mooring for cruise ship visitation.

There is also uncertainty around what impact climate change will have on ecosystems and, by extension, the ability of ecosystems to continue to provide both adaptation and mitigation services, as well as the broader suite of ESs (Jones, Hole, \& Zavaleta, 2012). For example, investing in coral reef conservation through establishment of a MPA (providing storm protection, food security and tourism industry opportunities) may face limits if the ocean warms to an extent where continued mass coral bleaching dislocates the coral reefs' integrity and the reef tips to an alternate state that does not provide the same adaptation services (Albright et al., 2018; Hughes et al., 2017; Mumby, Hastings, \& Edwards, 2007). Furthermore, climate change is generally not the only threat to habitat conservation. There is little reason to believe habitats that are the targets of investments from EbA projects that are also currently under threat at the margins - or even at risk of collapse - as a result of anthropogenic activities and global change processes, will not face the same threat of degradation, notwithstanding the adaptive response. Tackling food security, through the demonstration plot project, tackles these anthropogenic stressors - land conversion from forests in particular - at the root cause.

We recognize Indigenous Traditional Knowledge (ITK) specifically kastom management of natural resources remains important to Tanna communities and can be employed successfully in EbA (Nalau, Becken, Schliephack, et al., 2018). Engagement in agricultural innovation via demonstration plots and agricultural extension workers could be interpreted as the antithesis of ITK and be seen as an external intervention, however, if we take the view that ITK is just one layer in 'nested knowledge systems' (Nalau, Becken, Schliephack, et al., 2018, p. 851), a well-structured, demonstration plot and extension officer programme can lead to co-produced knowledge. As ITK is held and accumulated collectively, our proposed adaptation projects have potential to be fully integrated into the community actions and interests - a common factor of success (Hasan et al., 2018; Nalau, Becken, Schliephack, et al., 2018). Though this intervention could be construed as technocratic (it deploys specialists), a focus on immediate solutions (growing produce more intensively), which also supports a continuation of kastom management of agricultural resources, should ensure enduring local engagement (Granderson, 2018).

Our project budgets include line items for annual evaluation. Success can be measured by generic assessment criteria, such as effectiveness, equity, legitimacy and efficiency (Adger et al., 2005; Althaus, Bridgman, \& Davis, 2007). Measures of effectiveness need to have both a spatial and temporal element. Farming techniques that are successful in one area may not be so in others (Adger, Huq, Brown, Conway, \& Hulme, 2003). These projects should be considered equitable ( $98 \%$ of households undertaking some farming (Vanuatu National Statistics Office, 2009), however, formal CCAs can have some localized access impacts: for example, MPAs limit access to or activities in fishing grounds, which need to be managed in an open and egalitarian way. In the main, most evaluation tends towards objective methods and solicit little or no judgement from the subject; i.e. the communities of Tanna. Recently, subjective, participatory methods are being proposed, along two continuums - how it is defined and how it is monitored (Clarke et al., 2019; Jones, 2019).

The combined subsistence gardens, extension officers, and tree nursery project components fit within the funding envelope for major funding institutions, such as a 'medium-sized project' from the Global Environment Facility (less than $\$ 2 \mathrm{~m}$ ). The addition of the community radio component pushes the project into the 'full-sized project' envelope. Hasan et al. (2018) argue that projects that are shorter in length and have a clear, singular agenda are more likely to succeed. As proposed, this project is of five year's duration, therefore to mitigate the risk of being unsuccessful, a level of cofunding - a further attribute of successful completion - by the Vanuatu government (either cash or in-kind) would better ensure that the intervention will be successfully and fully implemented.

Approaches to planning and decision making that use EbA and resilience-thinking provide a significant opportunity for SIDS to adapt to climate change threats, while addressing other sustainable development and equity goals, such as those laid out in the United Nations 2030 Agenda for Sustainable Development. But despite these demonstrated benefits, the potential of EbA solutions is not being fully realized (Munang et al., 2013). Although there is evidence EbA is beginning to influence policy-making and planning, it remains limited and the full suite of co-benefits is not being recognized (Pramova, Locatelli, Brockhaus, \& Fohlmeister, 2012). Once these cobenefits are demonstrated, in many instances, the business case becomes overwhelmingly positive, as our SCBA has shown. Demonstrating these benefits using SBCA that employs economic valuation of ESs is a vital step in making the business case. 


\section{Conclusion}

Our study presents an SBCA of a targeted programme of EbA interventions on Tanna for the purposes of improving community resilience to climate change. We employ methods for economic valuation of ESs in the assessment of positive environmental externalities. Our results show that very considerable social benefit is derived from specific interventions that aim to improve the productivity of subsistence gardens by the implementation of demonstration plots and agricultural extension workers, which also simultaneously take the pressure off deforestation and improve well-being, even under conditions of a growing population. Increasing the intensity of food production reduces pressure on a range of resource management threats and can potentially be adopted by all households on Tanna. The initial project investment is, however, considerable, putting it into either the medium- or full-sized project envelope for major funding organizations. From a more modest investment. increasing the community capacity to balance formal forest and reef conservation with customary management can provide small, but nevertheless important complimentary social benefits, but does not produce the substantial social returns on investment. Given the lack of global progress towards reducing greenhouse gas emissions, the impacts of climate change are likely to accelerate. If the impacts of climate change on SIDS are to be mitigated and resilience to environmental change for rural communities is to be supported, then EbA approaches that improve food production (or reduce food insecurity), whilst also alleviating pressure on remaining natural habitats, provide potentially fruitful avenues and should be high priority for major project sponsors.

\section{Acknowledgements}

We are also grateful for the on-the-ground assistance of 'Uncle Allan' (Allan Dan), as the Ecosystem and Socio-economic Resilience Analysis and Mapping (ESRAM) Tanna Island project officer, the Tafea Provincial Government for support and cooperation, the Tanna community for their hospitality, support, collaboration and sharing of local knowledge, and the three anonymous reviewers for their insightful comments.

\section{Disclosure statement}

No potential conflict of interest was reported by the authors.

\section{Funding}

This research was made possible by programme funding through the Pacific Ecosystem-based Adaptation to Climate Change (PEBACC) project, a fiveyear initiative implemented by the Secretariat of the Pacific Regional Environment Programme (SPREP) in partnership with the Governments of Fiji, Solomon Islands and Vanuatu and the funding support of the German Federal Ministry of the Environment, Nature Conservation, and Nuclear Safety. The research was also supported by a grant to Griffith University from a private charitable trust that wishes to remain anonymous.

\section{Notes on contributors}

Andrew Buckwell is a Senior Research Assistant at Griffith Business School. He is an applied environmental economist with research interests in non-market valuation of ecosystem services, ecosystem-based adaptation and in developing research techniques for examining natural resource management issues, particularly for small island developing states and forest communities.

Dan Ware is a Research Fellow at Griffith University, Centre for Coastal Management and Climate Change Response Program. He is a geographer by training, with experience in coastal planning and climate change risk assessment and management. His current research interests are in design of ecosystem-based adaptations for small island developing sates. He currently undertaking a $\mathrm{PhD}$.

Christopher Fleming is a Professor and MBA Director at Griffith Business School and a founding member of the Griffith Centre for Sustainable Enterprise. Chris is an applied micro-economist with research interests that include, social and economic project/program evaluation, natural resource and environmental economics, sustainable development, the economic determinants of subjective wellbeing and the sustainable management of natural resources.

Jim C. R. Smart is an Associate Professor in the Griffith School of Environment and the Australian Rivers Institute. His research expertise includes resource economics, environmental valuation, and examining stakeholder interactions and conflicting objectives in resource management.

Brendan Mackey is a Professor at the Griffith University School of Environment and serves as Director of the Griffith Climate Change Response Program, which leads the university's research into climate change adaptation and mitigation problems. He has a long-standing interest in the nexus between science, policy, social ethics, law, and sustainability. His current research is focused on climate change adaptation challenges in Pacific islands and the challenge of protecting the world's remaining primary forests. He is a Coordinating Lead Author for the Intergovernmental Panel on Climate Change (IPCC) Sixth Assessment Report, Chapter 11.

Johanna Nalau is an adaptation scientist with a $\mathrm{PhD}$ in climate change adaptation from Griffith University. Johanna's research is focused on understanding how, why, and when people and institutions make decisions to adapt to climate change, and what role science can and should play in that process. Johanna is a Lead Author for the Intergovernmental Panel on Climate Change (IPCC) 6th Assessment report in Working Group II Chapter 15 Small Islands.

Allan Dan is a Strategic Policy and Technical Programmes Officer for Island and Ocean Ecosystems and Ecosystem-Based Adaptation for the Secretariat of the Pacific Regional Environment Programme. Allan is based in Vanuatu and has interests in community well-being and community management of natural resources.

\section{ORCID}

Andrew Buckwell (D) http://orcid.org/0000-0002-6441-9674 Dan Ware (D) http://orcid.org/0000-0002-6208-4399

Christopher Fleming (D) http://orcid.org/0000-0001-7596-7775

James C. R. Smart (D) http://orcid.org/0000-0003-4597-1460

Brendan Mackey (D) http://orcid.org/0000-0003-1996-4064

Johanna Nalau (D) http://orcid.org/0000-0001-6581-3967

\section{References}

Adesina, A. A., \& Zinnah, M. M. (1993). Technology characteristics, farmers' perceptions and adoption decisions: A Tobit model application in Sierra Leone. Agricultural Economics, 9(4), 297-311.

Adger, W. N., Arnell, N. W., \& Tompkins, E. L. (2005). Successful adaptation to climate change across scales. Global Environmental Change, 15(2), 77-86.

Adger, W. N., Huq, S., Brown, K., Conway, D., \& Hulme, M. (2003). Adaptation to climate change in the developing world. Progress in Development Studies, 3(3), 179-195.

Agardy, T., Di Sciara, G. N., \& Christie, P. (2011). Mind the gap: Addressing the shortcomings of marine protected areas through large scale marine spatial planning. Marine Policy, 35(2), 226-232. 
Albright, R., Takeshita, Y., Koweek, D. A., Ninokawa, A., Wolfe, K., Rivlin, T., ... Caldeira, K. (2018). Carbon dioxide addition to coral reef waters suppresses net community calcification. Nature, 555(7697), 516-519.

Althaus, C., Bridgman, P., \& Davis, G. (2007). The Australian policy handbook. Crows Nest: Allen \& Unwin.

Amos, J. (2007). Vanuatu fishery resource profiles. Apia, Samoa. Retrieved from https://www.sprep.org/att/publication/000557_IWP_PTR49.pdf

Anderson, T. (2006). On the economic value of customary land in Papua New Guinea. Pacific Economic Bulletin, 21(1), 138-152.

Andrade, Á, Córdoba, R., Dave, R., Girot, P., Herrera-F, B., Munroe, R., ... Vengara, W. (2011). Draft principles and guidelines for integrating ecosystem-based approaches to adaptation in project and policy design: A discussion document. Retrieved from https://portals.iucn.org/library/ efiles/documents/2011-064.pdf

Andrew, V., Andasua, W., \& Baynes, J. (2016). Forest extension in the Eastern Highlands of Papua New Guinea. Small-scale and community forestry and the changing nature of forest landscapes (pp. 18-22), 1115 October 2015, Sunshine Coast, Australia.

Asian Development Bank. (2003). Priorities of the people: Hardship in Vanuatu. Manila. Retrieved from https://www.adb.org/sites/default/ files/publication/29744/hardship-vanuatu.pdf

Asian Development Bank. (2007). Poverty impact analysis: Selected tools and applications. Manila. Retrieved from https://www.adb.org/sites/ default/files/publication/27972/poverty-impact-analysis.pdf

Australian Government. (2018). Indigenous rangers - working on country. Retrieved from https://www.pmc.gov.au/indigenous-affairs/ environment/indigenous-rangers-working-country

Barnett, J. (2001). Adapting to climate change in Pacific Island countries: The problem of uncertainty. Regional Environmental Change, 29(1), 977-993.

Barnett, J. (2011). Dangerous climate change in the Pacific Islands: Food production and food security. Regional Environmental Change, 11(1), 229-237.

Berrang-Ford, L., Ford, J. D., \& Paterson, J. (2011). Are we adapting to climate change? Global Environmental Change, 21(1), 25-33.

Betzold, C. (2015). Adapting to climate change in small island developing states. Climatic Change, 133(3), 481-489.

Blanco, J., Pascal, L., Ramon, L., Vandenbroucke, H., \& Carrière, S. (2013). Agrobiodiversity performance in contrasting island environments: The case of shifting cultivation in Vanuatu, Pacific. Agriculture, Ecosystems \& Environment, 174, 28-39.

Boardman, A., Greenberg, D., Vining, A. R., \& Weimer, D. L. (2017). Costbenefit analysis: Concepts and practice. Cambridge: Cambridge University Press.

Brosi, B. J., Balick, M. J., Wolkow, R., Lee, R., Kostka, M., Raynor, W., ... Lee Ling, D. (2007). Cultural erosion and biodiversity: Canoe-making knowledge in Pohnpei, Micronesia. Conservation Biology, 21(3), 875879.

Buncle, A. (2013). Informing climate-resilient development: The application of cost-benefit analysis (CBA) in the pacific adaptation to climate change (PACC) programme: Experiences and lessons learned on capacity building. SPREP. Retrieved from https://www.unenvironment.org/resources/ report/informing-climate-resilient-development-application-costbenefit-analysis-cba-pacc

Carpenter, S., DeFries, R., Dietz, T., Mooney, H., Polasky, S., Reid, W. V., \& Scholes, R. J. (2006). ECOLOGY: Enhanced: Millennium ecosystem assessment: Research needs. Science, 314(5797), 257-258.

Christie, P. (2004). Marine protected areas as biological successes and social failures in Southeast Asia. American Fisheries Society symposium (Vol. 42, pp. 155-164).

Cinner, J., \& Aswani, S. (2007). Integrating customary management into marine conservation. Biological Conservation, 140(3-4), 201-216.

Clarke, T., McNamara, K., Clissold, R., \& Nunn, P. (2019). Communitybased adaptation to climate change: Lessons from Tanna Island, Vanuatu. Island Studies Journal, 14(1), 59-80.

Clarke, W., \& Thaman, R. (1993). Agroforestry in Melanesia. Tokyo: United Nations University Press.

Clifton, R., \& Wharton, J. (1971). Risk, uncertainty, and the subsistence farmer: Technological innovation and resistance to change in the context of survival. In George Dalton (Ed.), Studies in economic anthropology (pp. 151-180). Washington, DC: American Anthropological Association.

Conley, T. G., \& Udry, C. R. (2010). Learning about a new technology: Pineapple in Ghana. American Economic Review, 100(1), 35-69.

Department of Forests. (2011). Vanuatu forest policy. Port Vila, Vanuatu. Retrieved from https://cn.china.cn/2011images/vanuatu/NFP_ Comprehensive_June_2011.pdf

Dercon, S., \& Christiaensen, L. (2011). Consumption risk, technology adoption and poverty traps: Evidence from Ethiopia. Journal of Development Economics, 96(2), 159-173.

Dumas, S. E., Lungu, L., Mulambya, N., Daka, W., McDonald, E., Steubing, E., ... Travis, A. J. (2016). Sustainable smallholder poultry interventions to promote food security and social, agricultural, and ecological resilience in the Luangwa Valley, Zambia. Food Security, 8(3), 507-520.

Eklund, P. (1983). Technology development and adoption rates: Systems approach for agricultural research and extension. Food Policy, 8(2), 141-153.

FEBA. (2018). Making ecosystem-based adaptation effective. Retrieved from https://www.iucn.org/sites/dev/files/feba_eba_qualification_and_ quality_criteria_final_en.pdf

Feder, G., Just, R. E., \& Zilberman, D. (1985). Adoption of agricultural innovations in developing countries: A survey. Economic Development and Cultural Change, 33(2), 255-298.

Fleming, E. (2007). Agricultural productivity change in Pacific island countries. Pacific Economic Bulletin, 22(3), 32-47.

Ford, J. D., Berrang-Ford, L., Lesnikowski, A., Barrera, M., \& Heymann, S. J. (2013). How to track adaptation to climate change: A typology of approaches for national-level application. Ecology and Society, 18(3), 40.

Foster, A. D., \& Rosenzweig, M. R. (1995). Learning by doing and learning from others: Human capital and technical change in agriculture. Journal of Political Economy, 103(6), 1176-1209.

Gerbeaux, P., Kami, T., Clarke, P., \& Gillespie, T. (2007). Shaping a sustainable future in the Pacific: IUCN regional program for Oceania 2007-2012. IUCN Regional Office for Oceania, Suva. Retrieved from: https://www.iucn.org/sites/dev/files/import/downloads/iucn_strategic_ priorities_1.pdf

Granderson, A. A. (2018). Value conflicts and the politics of risk: Challenges in assessing climate change impacts and risk priorities in rural Vanuatu. Climate and Development, 10(6), 481-494.

Guidetti, P. (2007). Potential of marine reserves to cause communitywide changes beyond their boundaries. Conservation Biology, 21(2), 540-545.

Harrison, S., Karim, S., Alauddin, M., \& Harrison, R. (2016). The contribution of agroforestry to economic development in Fiji and Vanuatu. Promoting sustainable agriculture and agroforestry to replace unproductive land use in Fiji and Vanuatu (pp. 9-18). Australian Centre for International Agricultural Research (ACIAR).

Hasan, S., Smart, J., Fleming, C., \& Mackey, B. (2018). Factors influencing the outcomes of climate change adaptation projects in the Pacific Island countries: A metaanalysis. Pacific climate change conference, 21-23 February 2018, Wellington.

Hernández, F., Urkiaga, A., De las Fuentes, L., Bis, B., Chiru, E., Balazs, B., \& Wintgens, T. (2006). Feasibility studies for water reuse projects: An economical approach. Desalination, 187(1), 253-261.

Hickey, F. R. (2008). Nearshore fisheries and human development in Vanuatu and other parts of Melanesia. SPC Traditional Marine Resource Management and Knowledge Information Bulletin, 24(1), 9-18.

Hughes, T., Barnes, M. L., Bellwood, D. R., Cinner, J., Cumming, G. S., Jackson, J. B. C., ... Scheffer, M. (2017). Coral reefs in the Anthropocene. Nature, 546, 82-90.

IPCC. (2014). Climate change 2014: Synthesis report. In Pachauri, R., Allen, M., Barros, V., Broome, J., Cramer, W., Christ, R., ... Dasgupta, P. (Eds.), Contribution of working groups I, II and III to the fifth assessment report of the intergovernmental panel on climate change. Geneva: IPCC.

James, P. A., Smart, J. C., Smith, J., Bulling, M. T., Beed, F. D., \& Luwandagga, D. (2011). The effect of participation in the Ugandan National Agricultural Advisory Services on willingness to pay for extension services. African Journal of Agricultural and Resource Economics, 6 (1), 1-19. 
Jones, H., Hole, D., \& Zavaleta, E. (2012). Harnessing nature to help people adapt to climate change. Nature Climate Change, 2(7), 504-509.

Jones, L. (2019). Resilience isn't the same for all: Comparing subjective and objective approaches to resilience measurement. Wiley Interdisciplinary Reviews: Climate Change, 10(1), e552.

Krishnan, P., \& Patnam, M. (2014). Neighbors and extension agents in Ethiopia: Who matters more for technology adoption? American Journal of Agricultural Economics, 96(1), 308-327.

Lamanda, N., Malézieux, E., \& Martin, P. (2006). Structure and dynamics of coconut-based agroforestry systems in Melanesia: A case study from the Vanuatu Archipelago. In Tropical homegardens (pp. 105-121). Dordrecht: Springer.

Langat, B. K., Ngéno, V. K., Nyangweso, P. M., Mutwol, M. J., Kipsat, M. J., Gohole, L., \& Yaninek, S. (2013). Drivers of technology adoption in a subsistence economy: The case of tissue culture bananas in Western Kenya. Invited paper presented at the 4th international conference of the African Association of Agricultural Economists (pp. 1-17).

Leary, N. A. (1999). A framework for benefit-cost analysis of adaptation to climate change and climate variability. Mitigation and Adaptation Strategies for Global Change, 4(3-4), 307-318.

Lester, S. E., Halpern, B. S., Grorud-Colvert, K., Lubchenco, J., Ruttenberg, B. I., Gaines, S. D., ... Warner, R. R. (2009). Biological effects within notake marine reserves: A global synthesis. Marine Ecology Progress Series, 384(1), 33-46.

Lindstrom, L. (1982). Leftamap Kastom: The political history of tradition on Tanna, Vanuatu. The Australian Journal of Anthropology, 13(4), 316-329.

Lindstrom, L. (2011). Naming and memory on Tanna, Vanuatu. In Elfriede Hermann (Ed.), Changing contexts, shifting meanings: Transformations of cultural traditions in Oceania (pp. 141-156). Honolulu: University of Hawaii Press.

Mackey, B., \& Ware, D. (2018). Limits to capital works adaptation in the coastal zones and Islands: Lessons for the Pacific. In Walter Leal Filho and Johanna Nalau (Eds.), Limits to climate change adaptation (pp. 301-323). Cham: Springer.

Mackey, B., Ware, D., Nalau, J., Buckwell, A., Smart, J., Fleming, C., ... Hallgren, W. (2017). Ecosystem and Socio-economic Resilience Analysis and Mapping (ESRAM) and associated works at multiple scales in Vanuatu. (Secretariat for the Pacific Regional Environment Programme, Ed.). Apia, Samoa. Retrieved from https://www.griffith. edu.au/_data/assets/pdf_file/0023/528080/vanuatu-ecosystem-socioeconomic-resilience-analysis-mapping.pdf

Mael, H. S. (2013). Climate change and agriculture in Vanuatu: A study of crops and farming system. Food and Agriculture Organisation of the United Nations. Retrieved from https://www.nab.vu/sites/default/files/ nab/documents/17/02/2014\%20-\%2014:24/agriculture_and_climate_ change_in_vanuatu.pdf

Marglin, S. A. (1965). Insurance for innovators. Appendix B in policies for promoting agricultural development. Cambridge: Center for International Studies, Massachusetts Institute of Technology.

Marine Conservation Institute. (2018). MPAtlas [On-line]. Retrieved from http://www.mpatlas.org/

Mascia, M. B., Claus, C. A., \& Naidoo, R. (2010). Impacts of marine protected areas on fishing communities. Conservation Biology, 24(5), 14241429.

Millennium Ecosystem Assessment. (2005). Millennium ecosystem assessment. Ecosystems and human well-being: Current state and trends. World Resources Institute, Washington, DC, États-Unis.

Moritz, C., Ens, E. J., Potter, S., \& Catullo, R. A. (2013). The Australian monsoonal tropics: An opportunity to protect unique biodiversity and secure benefits for Aboriginal communities. Pacific Conservation Biology, 19(4), 343-355.

Moser, C. M., \& Barrett, C. B. (2006). The complex dynamics of smallholder technology adoption: The case of SRI in Madagascar. Agricultural Economics, 35(3), 373-388.

Mumby, P., Hastings, A., \& Edwards, H. J. (2007). Thresholds and the resilience of Caribbean coral reefs. Nature, 450(7166), 98-101.

Munang, R., Thiaw, I., Alverson, K., Mumba, M., Liu, J., \& Rivington, M. (2013). Climate change and ecosystem-based adaptation: A new pragmatic approach to buffering climate change impacts. Current Opinion in Environmental Sustainability, 5(1), 67-71.

Nakano, Y., Tsusaka, T. W., Aida, T., \& Pede, V. O. (2018). Is farmer-tofarmer extension effective? The impact of training on technology adoption and rice farming productivity in Tanzania. World Development, 105(1), 336-351.

Nalau, J., Becken, S., \& Mackey, B. (2018). Ecosystem-based adaptation: A review of the constraints. Environmental Science \& Policy, 89(1), 357364.

Nalau, J., Becken, S., Schliephack, J., Parsons, M., Brown, C., \& Mackey, B. (2018). The role of indigenous and traditional knowledge in ecosystembased adaptation: A review of the literature and case studies from the Pacific Islands. Weather, Climate, and Society, 10(4), 851-865.

Nehrbass, K. (2012). A comprehensive comparison of lexemes in the major languages of Tanna, Vanuatu (SIL eBook). SIL International. Retrieved from https://www.researchgate.net/profile/Kenneth_Nehrbass/publi cation/265068678_A_Comprehensive_Comparison_of_Lexemes_i n_the_Major_Languages_of_Tanna_Vanuatu/links/552686910cf21e1 26f9df44f/A-Comprehensive-Comparison-of-Lexemes-in-the-Majo r-Languages-of-Tanna-

Nyyssölä, M., Pirttilä, J., \& Sandström, S. (2014). Technology adoption and food security in subsistence agriculture: Evidence from a group-based aid project in Mozambique. Finnish Economic Papers, 27(1), 1-33.

Pascal, N., Molisa, V., Wendt, H., Brander, L., Fernandes, L., Salcone, J., \& Seidle, A. (2015). Economic assessment and valuation of marine ecosystem services, Vanuatu. A report to the MACBIO project. Suva, Fiji: MACBIO.

Pramova, E., Locatelli, B., Brockhaus, M., \& Fohlmeister, S. (2012). Ecosystem services in the national adaptation programmes of action. Climate Policy, 12(4), 393-409.

Pröpper, M., \& Haupts, F. (2014). The culturality of ecosystem services. Emphasizing process and transformation. Ecological Economics, 108 (1), 28-35.

Regenvanu, R., Wyatt, S. W., \& Tacconi, L. (1997). Changing forestry regimes in Vanuatu: Is sustainable management possible? [Special issue]. The Contemporary Pacific, 9(1), 73-96.

Republic of Vanuatu. (2016a). Tafea Province mini census 2016 key facts. Port Vila, Vanuatu. Retrieved from https://vnso.gov.vu/index.php/2uncategorised/153-mini-census

Republic of Vanuatu. (2016b). Vanuatu 2030: The people's plan: National sustainable development plan 2016 to 2030. Port Vila, Vanuatu. Retrieved from https://www.gov.vu/attachments/article/26/ Vanuatu2030-EN-FINAL-sf.pdf

Riley, J., Parra, J., Sukhdev, P., Ong, J. E., Page, S., Kramer, R., ... Zavaleta, E. S. (2009). Mangrove forests: Resilience, protection from tsunamis, and responses to global climate change. Estuarine, Coastal and Shelf Science, 76(1), 1-13.

Ruddle, K., \& Hickey, F. R. (2008). Accounting for the mismanagement of tropical nearshore fisheries. Environment, Development and Sustainability, 10(5), 565-589.

Savage, A., McIver, L., \& Schubert, L. (2019). The nexus of climate change, food and nutrition security and diet-related non-communicable diseases in Pacific Island Countries and Territories. Climate and Development, 1-14.

SPREP. (2018). PEBACC home. Retrieved from https://www.sprep.org/ pebacc

Stuart-Hill, G., Diggle, R., Munali, B., Tagg, J., \& Ward, D. (2005). The event book system: A community-based natural resource monitoring system from Namibia. Biodiversity and Conservation, 14(11), 26112631

Suvedi, M., Ghimire, R., \& Kaplowitz, M. (2017). Farmers' participation in extension programs and technology adoption in rural Nepal: A logistic regression analysis. The Journal of Agricultural Education and Extension, 23(2), 1-21.

Thaman, R., Clarke, W., Manner, H., Decker, B., \& Ali, I. (1993). Agroforestry in the Pacific Islands: Systems for sustainability. Tokyo: United Nations University Press.

UN. (2018). Sustainable development goals knowledge platform. Retrieved from https://sustainabledevelopment.un.org/ 
UNDP. (2010). Evaluation of UNDP contribution to environmental management for poverty reduction: The poverty-environment nexus. Retrieved from https://erc.undp.org/evaluation/evaluations/detail/ 4784

UNDP. (2012). Nguna-Pele marine and land protected area network, Vanuatu. New York. Retrieved from https://www.equatorinitiative. org/wp-content/uploads/2017/05/case_1348163605.pdf

UNEP. (2016). The adaptation finance gap report 2016. United Nations Environment Programme (UNEP) Nairobi. Retrieved from https:// www.unenvironment.org/resources/adaptation-gap-report

United Nations University. (2015). World risk report. Retrieved from http://www.worldriskreport.org

van der Ploeg, S., \& de Groot, R. (2010). The TEEB valuation database - a searchable database of 1310 estimates of monetary values of ecosystem services. Wageningen, The Netherlands: Foundation for Sustainable Development.

Vanuatu National Statistics Office. (2009). National population and housing census. Port Vila, Vanuatu. Retrieved from https://vnso.gov.vu/ index.php/census-and-surveys/census/censuses

Venn, T. J., \& Quiggin, J. (2007). Accommodating indigenous cultural heritage values in resource assessment: Cape York Peninsula and the Murray-Darling Basin, Australia. Ecological Economics, 61(2), 334-344.

Weber, J. G. (2012). Social learning and technology adoption: The case of coffee pruning in Peru. Agricultural Economics, 43(1), 73-84.

World Bank. (2009). Convenient solutions to an inconvenient truth: Ecosystem-based approaches to climate change. Retrieved from https:// siteresources.worldbank.org/ENVIRONMENT/Resources/ESW_ EcosystemBasedApp.pdf 